Louisiana State University

LSU Digital Commons

Faculty Publications

Department of Biological Sciences

$4-29-2010$

\title{
Transcriptional factors that promote formation of white adipose tissue
}

Ursula A. White

Louisiana State University

Jacqueline M. Stephens

Louisiana State University

Follow this and additional works at: https://digitalcommons.Isu.edu/biosci_pubs

\section{Recommended Citation}

White, U., \& Stephens, J. (2010). Transcriptional factors that promote formation of white adipose tissue. Molecular and Cellular Endocrinology, 318 (1-2), 10-14. https://doi.org/10.1016/j.mce.2009.08.023

This Article is brought to you for free and open access by the Department of Biological Sciences at LSU Digital Commons. It has been accepted for inclusion in Faculty Publications by an authorized administrator of LSU Digital Commons. For more information, please contact ir@lsu.edu. 


\title{
Transcriptional factors that promote formation of white adipose
}

\section{tissue}

\author{
Ursula A. White and Jacqueline M. Stephens* \\ Department of Biological Sciences, Louisiana State University, Baton Rouge, LA 70803, USA
}

\section{Abstract}

Adipocytes are highly specialized cells that play a major role in energy homeostasis in vertebrate organisms. Excess adipocyte size or number is a hallmark of obesity, which is currently a global epidemic. Obesity is a major risk factor for the development of type II diabetes (T2DM), cardiovascular disease, and hypertension. Obesity and its related disorders result in dysregulation of the mechanisms that control the expression of metabolic and endocrine related genes in adipocytes. Therefore, understanding adipocyte differentiation is relevant not only for gaining insight into the pathogenesis of metabolic diseases, but also for identifying proteins or pathways which might be appropriate targets for pharmacological interventions. Significant advances towards an understanding of the regulatory processes involved in adipocyte differentiation have largely been made by the identification of transcription factors that contribute to the adipogenic process. It is important to note that the developmental origin of white and brown fat is distinct and different precursor cells are involved in the generation of these different types of adipose tissue (reviewed in Lefterova and Lazar, 2009; Seale et al., 2009). Several transcription factors, notably PPAR $\gamma$, several members of the C/EBP and KLF families, STAT5, and SREBP-1c, have been shown to have significant roles in promoting adipogenesis. More comprehensive reviews on negative and positive regulators of adipogenesis have been published in the past year (reviewed in Christodoulides et al., 2009; Lefterova and Lazar, 2009). Though many proteins are known to negatively regulate adipogenesis, including Wnts, KLFs, the E2F family of transcription factors, CHOP, Delta-interacting protein A, ETO/MTG8, and members of the GATA and forkhead transcription factor families, this review will focus on transcription factors that positively impact the development of white adipose tissue.

\section{Keywords}

Adipocyte; PPAR; C/EBP; STAT5; KLF; SREBP

\section{Introduction and history}

\begin{abstract}
Interestingly, the majority of studies that have identified transcriptional regulators of adipogenesis have been performed in vitro. These studies have been primarily conducted in the 3T3-L1 or 3T3-F442A murine preadipocyte cell lines that were originally generated in the laboratory of Dr. Howard Green at Harvard University (Green and Kehinde, 1975, 1976). In the last 35 years, these cells lines have been used by thousands of investigators world-wide. Many cell types cannot be adequately studied in vitro because the cultured cells do not possess the properties of cells in vivo. However, the preadipocyte cell lines
\end{abstract}

(C) 2009 Elsevier Ireland Ltd. All rights reserved.

"Corresponding author at: Louisiana State University, Department of Biological Sciences, 202 Life Sciences Bldg., Baton Rouge, LA 70803, USA. Tel.: +1 225578 1749; fax: +1 225578 2597. jsteph1 @1su.edu (J.M. Stephens). . 
developed by Dr. Green have been extremely useful model systems for adipocyte biologists, and the data obtained in these cells have been validated from less mechanistic in vivo studies in the last decade. In vivo, adipocytes have three primary characteristics, which include lipid storage, insulin sensitivity, and endocrine properties. The 3T3-L1 cells have all three of these notable characteristics of fat cells. In addition to being widely used to study adipocyte development, the identity and/or characterization of many adipocyte specific genes have been identified using this cell line.

In the late 1980s, a commentary by Dr. Steven McKnight, now at the Carnegie Institution of Washington, and Dr. M. Daniel Lane at John Hopkins University indicated that C/EBP $\alpha$ was a key metabolic regulator of energy metabolism (McKnight et al., 1989). Numerous studies have since confirmed the role of $\mathrm{C} / \mathrm{EBP} \alpha$ and other C/EBP family members in energy balance and defined roles for these transcription factors in adipocyte differentiation (reviewed in Farmer, 2006). In 1994, two prominent laboratories independently identified PPAR $\gamma$ as an important modulator of adipocyte differentiation. Studies by Dr. Mitch Lazar's group at the University of Pennsylvania observed the induction of PPAR $\gamma$ during adipogenesis (Chawla et al., 1994), and experiments by Dr. Bruce Speigelman's Laboratory at Harvard Medical School revealed that PPAR $\gamma$ was a transcription factor which bound to an enhancer element in the aP2 promoter and conferred its fat-specific expression (Tontonoz et al., 1994). The early 1990s was also the time that Drs. Michael Brown and Joseph Goldstein from the University of Texas Southwestern identified SREBP-1 (Yokoyama et al., 1993), also termed ADD1, whose expression was observed to play a role in adipocyte determination by the Spiegelman Laboratory (Tontonoz et al., 1993). Since then, several other transcription factors have been found to promote adipocyte development.

Studies of the aP2 gene, and use of its regulatory sequences, have led to significant discoveries in adipocyte biology and metabolic diseases. aP2 is an abundantly expressed adipocyte gene that was first discovered in 1984 (Bernlohr et al., 1984), and one of the earliest studies on PPAR $\gamma$ identified this transcription factor for its ability to bind to an enhancer element in the aP2 promoter and mediate its adipocyte-enriched expression (Tontonoz et al., 1994). Since its discovery, the aP2 promoter has been used by hundreds of laboratories to construct transgenes that have largely fat-specific expression. A lesser known historical fact is that c-fos was also shown to bind to the aP2 promoter just 124 base pairs upstream of the transcriptional start site (Distel et al., 1987). As means of introduction, this was one of the first studies to propose that AP-1 proteins were regulators of adipocyte gene expression.

\subsection{AP-1 transcription factors}

Members of the activating protein-1 (AP-1) family of transcription factors are well-known regulators of cellular proliferation and differentiation. AP-1 is a collective term referring to dimeric transcription factors composed of c-Jun, Jun-B, Jun-D and c-Fos, Fos-B, Fra-1, or Fra-2 subunits that bind to a common DNA site, the AP-1-binding site (reviewed in Karin et al., 1997). Initial studies by the Spiegelman Laboratory showed that c-Fos was involved in the modulation of aP2 expression (Distel et al., 1987), and accordingly it was shown that the expression of c-Jun, c-Fos, Jun-B, Fos-B, and Fra-1 was induced immediately after the induction of adipocyte differentiation (Stephens et al., 1992, 1993). Although the role of individual AP-1 family members in adipogenesis has not been elucidated, there is strong evidence to indicate the importance of these transcription factors in vivo. Transgenic mice were generated that express a dominant-negative protein that prevents the DNA binding of B-ZIP transcription factors of both the C/EBP and Jun families under the control of the adipose-enriched aP2 enhancer/promoter. These mice have no white adipose tissue throughout life (Moitra et al., 1998). Collectively, these studies suggest that the induction and expression of AP-1 transcription factors play a role in fat cell differentiation. 


\subsection{STAT (signal transducers and activators of transcription)}

In the last decade, several groups have studied the modulation and function of STAT proteins during adipogenesis and in mature fat cells. The STAT family of mammalian transcription factors is comprised of seven proteins (STATs 1, 2, 3, 4, 5A, 5B, and 6) which, in response to stimulation of various receptors, mainly those for cytokines, are phosphorylated on tyrosine residues causing their translocation to the nucleus. Each STAT family member shows a distinct pattern of activation by cytokines and upon nuclear translocation can regulate the transcription of particular genes (reviewed in Darnell, 1997). STATs have been shown to bind to distinct DNA sequences, and this binding regulates the transcription of specific genes (reviewed in Darnell, 1997; Pellegrini and Dusanter-Fourt, 1997). Since the tissue distribution and function of each STAT is unique, the regulation of tissue-specific genes appears to be a physiological role for these proteins (reviewed in Schindler and Darnell, 1995). This hypothesis is supported by numerous reports which demonstrate that specific STATs are activated differently by growth factors and cytokines, and STAT activation can be cell type dependent. In addition, transgenic knockout experiments have revealed crucial roles for each known mammalian STAT (reviewed in Darnell, 1997), and cell-specific functions for STAT family members have also been identified (reviewed in Schindler, 2002).

The first studies on STAT expression in 3T3-L1 cells revealed that STATs 1, 5A and 5B were highly induced during murine adipogenesis (Stephens et al., 1996). Similar results were observed during the in vitro differentiation of human preadipocytes (Harp et al., 2001). In addition, the ectopic expression of C/EBPs $\beta$ and $\delta$ in non-precursor cells results in an induction of adipogenesis (Wu et al., 1996) that is accompanied by an induction in STAT5A and STAT5B protein levels (Stephens et al., 1996). These two STAT5 proteins are also coordinately regulated with both PPAR $\gamma$ and C/EBP $\alpha$ in differentiating 3T3-L1 cells under a variety of conditions (Stewart et al., 1999). In 3T3-F442A preadipocytes, the ability of growth hormone to modulate adipogenesis is attenuated by STAT5 anti-sense oligonucleotides (Yarwood et al., 1999). Also, constitutively active STAT5 is capable of replacing the requirement for growth hormone in adipogenesis of these cells (Shang and Waters, 2003). Ectopic expression of STAT5A confers adipogenesis in 3T3-L1 preadipocytes (Nanbu-Wakao et al., 2002) and in two different non-precursor cell lines (Floyd and Stephens, 2003). Interestingly, STAT5B was not capable of conferring adipogenesis in non-precursor cells (Floyd and Stephens, 2003). Transgenic deletion of STAT5A, STAT5B, or both STAT5 genes in mice resulted in significantly reduced fat pad sizes compared to wild-type mice (Teglund et al., 1998). In primary cultures of adipose tissue from these animals, growth hormone did not stimulate lipolysis as it did in adipocytes from wild-type animals (Fain et al., 1999), suggesting that some of the effects of growth hormone on fat metabolism are dependent on STAT5 proteins. It should be noted that the increased expression of STAT5 proteins is not typically observed until after the induction of $\mathrm{C} / \mathrm{EBP} \alpha$ and PPAR $\gamma$ (refer to Fig. 1), yet the activation of STAT5 proteins in preadipocytes occurs prior to the induction in expression of PPAR $\gamma$ in 3T3-L1 cells (Floyd and Stephens, 2003). In fact, both STAT5 proteins are tyrosine phosphorylated and translocate to the nucleus within 15 min after the induction of adipogenesis (Baugh et al., 2007; Floyd and Stephens, 2003). Coupled with the observations that STAT5 null mice have fat pads onefifth normal size (Teglund et al., 1998), the data suggest that activation of STAT5 proteins may be an important driver of adipogenesis both in vitro and in vivo. This hypothesis is also supported by work indicating that one of the PPAR $\gamma$ promoters can be modulated by STAT5 (Kawai et al., 2007), which indicates that STAT5 activation might drive adipogenesis by inducing PPAR $\gamma$ expression. In summary, work by a variety of laboratories has demonstrated that STAT5 proteins are activated and induced during adipogenesis and play an important role in adipose tissue development. 


\subsection{Krüppel-like factors (KLFs)}

Krüppel-like zinc finger transcription factors (KLFs) are known to play diverse roles in cell differentiation and development in mammals. One protein in the KLF family, KLF15, was shown to be highly induced during adipocyte differentiation, and inhibition of KLF15 function or expression is accompanied by an inhibition of adipogenesis in 3T3-L1 cells (Mori et al., 2005). These studies also revealed that KLF15 could confer adipogenesis in non-precursor cells and result in the induction of PPAR $\gamma$ expression. Similar to KLF15, KLF5 expression is also highly induced during adipocyte differentiation in 3T3-L1 cells (refer to Fig. 1), and embryonic fibroblasts obtained from heterozygote KLF5 mice exhibit reduced adipogenesis (Oishi et al., 2005). KLFs are not only involved in lipid accumulation, but also appear to play a role in the ability of the adipocyte to be insulin sensitive, as indicated by studies showing that KLF15 is important in the expression of GLUT4 (Gray et al., 2002). KLF4 is also induced early in the differentiation process and can transactivate the C/EBP $\beta$ promoter in cooperation with Krox20 (Birsoy et al., 2008), another zinc finger transcription factor shown to stimulate adipogenesis (Chen et al., 2005). KLF6 has been shown to have a favorable effect on adipogenesis by inhibiting dlk1, an inhibitor of fat cell differentiation ( $\mathrm{Li}$ et al., 2005). Other members of the KLF family have been shown to have negative effects on adipogenesis. Emerging studies on the role of KLFs in adipocyte development will be critical for the identification of target genes in fat cells, as well as the likely discovery of both redundant and non-redundant functions of these transcription factors in adipocytes.

\subsection{Sterol regulatory element binding proteins (SREBPs)}

In 1993, studies by the Spiegelman group identified a basic helix-loop-helix transcription factor that was expressed in adipocytes and regulated during adipogenesis (Tontonoz et al., 1993). The protein was called ADD1 for adipocyte differentiation and determination. Two months later, this protein was labeled SREBP-1 by the Brown and Goldstein Laboratories, who named the transcription factor for its ability to bind sterol responsive elements within the promoter of the LDL receptor gene (Yokoyama et al., 1993). It is now known that there are three SREBP isoforms (SREBP-1a, -1c, and -2) that have been well characterized. SREBP-1a and $-1 \mathrm{c}$ are transcribed from the same gene, each by a distinct promoter, and the predominant SREBP-1 isoform in liver and adipose tissue is SREBP-1c. SREBP-2 is relatively selective in the transcriptional activation of cholesterol biosynthetic genes, and SREBP-1c has a greater role in regulating genes associated with fatty acid synthesis (reviewed in Eberle et al., 2004). Although there is clear evidence that SREBP is an insulin modulated transcription factor that is involved in the regulation of genes associated with cholesterol and lipid metabolism, studies indicate that SREBPs may not be critical for adipogenesis. Mice deficient in SREBP-1 do not have a significantly decreased amount of white adipose tissue, but SREBP-2 levels were increased, suggesting it might compensate for SREBP-1 in this animal model (Shimano et al., 1997). These in vivo studies are supported by additional transgenic studies where SREBP-1 deficient mice were crossed with $\mathrm{ob} / \mathrm{ob}$ (leptin deficient) mice, and it was found that SREBP-1 was not required for the development of obesity (Yahagi et al., 2002). These observations concluded that SREBP-1 regulation of lipogenesis was highly involved in the development of fatty livers but was not a determinant of obesity in this animal model (Yahagi et al., 2002). However, ectopic expression of a dominant-negative SREBP-1c was shown to attenuate adipocyte differentiation (Kim and Spiegelman, 1996). In addition, over expression of SREBP-1c enhanced the adipogenic activity of PPAR $\gamma$ (Kim and Spiegelman, 1996), and other studies suggest that SREBP-1c contributes to the generation of PPAR $\gamma$ ligands (Kim et al., 1998). In summary, in vitro studies support a role for SREBP-1 in adipogenesis, whereas in vivo studies indicate that SREBPs are not required for the production or expansion of adipose tissue. 


\subsection{C/EBP (CAAAT enhancer binding proteins)}

C/EBP transcription factors were the first family of transcription factors shown to play a critical role in the differentiation of fat cells in vitro. Today, we know that transgenic mice lacking both $\mathrm{C} / \mathrm{EBP} \beta$ and $\mathrm{C} / \mathrm{EBP} \delta$ or $\mathrm{C} / \mathrm{EBP} \alpha$ alone have defective adipocyte differentiation (Tanaka et al., 1997; Wang et al., 1995). Prior to these in vivo observations, the cascade of induction of these three C/EBP family members was revealed by McKnight and collaborators who showed that C/EBPs $\beta$ and $\delta$ were induced immediately after the induction of differentiation, whereas C/EBP $\alpha$ expression did not occur until 4-5 days after the initiation of differentiation (Cao et al., 1991) (refer to Fig. 1). This group also demonstrated that C/EBPs $\beta$ and $\delta$ were responsible for inducing C/EBP $\alpha$ expression (Yeh et al., 1995). Ectopic expression studies conducted by several laboratories demonstrated the adipogenic capabilities of C/EBP $\alpha$ or C/EBP $\beta$ alone, or in the presence of C/EBP $\delta$ (Lin and Lane, 1994; Wu et al., 1995, 1996; Yeh et al., 1995). Today, C/EBP $\alpha$ and PPAR $\gamma$ are considered the two primary transcription factors that mediate adipogenesis. However, cells lacking C/EBP $\alpha$ are capable of adipogenesis, but are not insulin sensitive (el Jack et al., 1999; Wu et al., 1999). Similar to SREBP-1c, there is evidence to indicate that C/EBPs may play a role in the induction of PPAR $\gamma$ ligands (Hamm et al., 2001). In summary, both in vitro and in vivo studies indicate a substantial role for $\mathrm{C} / \mathrm{EBP} \beta, \mathrm{C} / \mathrm{EBP} \delta$, and $\mathrm{C} / \mathrm{EBP} \alpha$ in adipogenesis. Although $\mathrm{C} / \mathrm{EBP} \alpha$ may not be absolutely required for lipid accumulation, this transcription factor clearly plays a role in conferring insulin sensitivity in adipocytes.

\subsection{PPAR[CR] (peroxisome proliferator-activated receptors[CR])}

Although a number of transcription factors, including those mentioned above, have been shown to have profound effects on fat cell differentiation and the expression of adipocyte genes, only one adipocyte transcription factor has been shown to be necessary for adipogenesis. Peroxisome proliferator-activated receptor gamma (PPAR $\gamma$ ) is a member of the nuclear hormone receptor superfamily that is required for the development of adipocytes, and deletion of PPAR $\gamma$ in mice results in placental dysfunction and embryonic lethality (Barak et al., 1999; Rosen et al., 1999). As previously noted, PPAR $\gamma$ was identified as a transcription factor induced during differentiation that bound an enhancer element within the aP2 promoter (Tontonoz et al., 1994). Although PPAR $\gamma$ is critical for adipogenesis, this transcription factor is induced after several other key transcriptional modulators of adipogenesis (Fig. 1). A remarkable finding in 1995 was that the insulin sensitizing drugs thiazolidinediones were ligands for PPAR $\gamma$ (Lehmann et al., 1995). This molecular study was pivotal in enhancing our understanding of the contributions of adipose tissue in insulin responsiveness. Many investigators were surprised to learn that activating a transcription factor whose expression was highly enriched in fat cells could contribute to whole animal insulin sensitivity. It is now known that adipocytes secrete several hormones that can affect the activity of other tissues, and studies of PPAR $\gamma$ have revealed that modulation of this transcription factor can contribute to systemic insulin resistance. Although PPAR $\gamma$ null mice are embryonic lethal (Barak et al., 1999; Rosen et al., 1999), transgenic mice lacking PPAR $\gamma$ specifically in adipose tissue exhibit greatly reduced sized fat pads and insulin resistance in fat and liver (He et al., 2003). However, PPAR $\gamma$ heterozygote mice have enhanced insulin sensitivity (Miles et al., 2000). Together, these studies suggest that the amount of PPAR $\gamma$ in adipose tissue is physiologically relevant.

In the last several years, several studies have examined pathways that are involved in regulating the levels of PPAR $\gamma$. In particular, the ubiquitin-proteasome system has emerged as an important regulator of PPAR $\gamma$ proteins (Floyd and Stephens, 2002; Hauser et al., 2000). In addition, a role for the ubiquitin-like protein, SUMO (Small Ubiquitin-like Modifier) in regulating PPAR $\gamma$ has been demonstrated by several groups (Floyd and Stephens, 2004; Ohshima et al., 2004; Pascual et al., 2005; Yamashita et al., 2004). The 
phosphorylation of PPAR $\gamma$ by MAPKs is also an important modulator of the activity of this transcription factor (reviewed in Burns and Vanden Heuvel, 2007). Although PPAR $\gamma$ knockdown prevents adipocyte differentiation, a recent study has indicated that PPAR $\gamma$ is not required for the maintenance of the differentiated adipocyte after the cells have undergone adipogenesis (Liao et al., 2007). These observations are supported by many anecdotal observations that indicate that PPAR $\gamma$ expression is decreased as adipocytes age in vitro. In addition, the increase of life span via caloric restriction results in the induction of Sirt1, a transcriptional modulator with deacetylase activity that represses PPAR $\gamma$ activity in vivo (Picard et al., 2004). This study also demonstrated that the repression of PPAR $\gamma$ by Sirt1 was evident in 3T3-L1 adipocytes. Collectively, studies by numerous laboratories have demonstrated the adipogenic capabilities of PPAR $\gamma$; however, the role of this transcription factor in mature adipocytes is less understood. Nonetheless, PPAR $\gamma$ expression and activity are controlled at multiple levels, including alternative promoter usage, tissue limited expression, phosphorylation, acetylation, ubiquitylation, and SUMOylation. The multiple levels of regulation of this transcription factor suggest that controlling the amount and activity of PPAR $\gamma$ is essential. The role of PPAR $\gamma$ in the development and treatment of diabetes is well established (reviewed in Leff et al., 2004), and the importance of PPAR $\gamma$ in humans is indicated by several loss-of-function mutations in the PPAR $\gamma$ gene that cause lipodystrophy and diabetes (Barroso et al., 1999; Doney et al., 2004; Monajemi et al., 2007; Semple et al., 2006).

\section{Conclusions}

In addition to the transcription factors described above that promote adipogenesis, there are several other transcription factor families that have been shown to have positive or negative effects on adipocyte differentiation (reviewed in Farmer, 2006; Lefterova and Lazar, 2009). The expression and activity of these transcription factors play a profound role in modulating a vast array of target genes that are important in conferring lipid accumulation, insulin sensitivity, and endocrine properties in mature fat cells. The identification and characterization of the target genes of adipogenic transcription factors has provided critical information in understanding the role of these proteins in both adipocyte differentiation and in adipose tissue. In summary, adipogenesis of white preadipocytes occurs as a result of a transcriptional cascade that involves the tightly regulated induction of numerous transcription factors, including STAT5, SREBP-1c, PPAR $\gamma$ and several members of the C/ EBPs and KLF families (refer to Fig. 1). In addition, many of these adipogenic factors possess the ability to regulate one another's gene expression, and there is substantial evidence to support functional redundancy in the ability of some of these transcription factor families to confer adipocyte development in vitro and in vivo. The future study of transcription factors that modulate adipocyte development and function is important and will likely continue to provide insight into our understanding of metabolic diseases including obesity and type II diabetes.

\section{References}

Barak Y, Nelson MC, Ong ES, Jones YZ, Ruiz-Lozano P, Chien KR, Koder A, Evans RM. PPAR gamma is required for placental, cardiac, and adipose tissue development. Mol. Cell. 1999; 4(4): 585-595. [PubMed: 10549290]

Barroso I, Gurnell M, Crowley VE, Agostini M, Schwabe JW, Soos MA, Maslen GL, Williams TD, Lewis H, Schafer AJ, Chatterjee VK, O'Rahilly S. Dominant negative mutations in human PPARgamma associated with severe insulin resistance, diabetes mellitus and hypertension. Nature. 1999; 402(6764):880-883. [PubMed: 10622252] 
Baugh JE Jr. Floyd ZE, Stephens JM. The modulation of STAT5A/GR complexes during fat cell differentiation and in mature adipocytes. Obesity (Silver Spring). 2007; 15(3):583-590. [PubMed: 17372307]

Bernlohr DA, Angus CW, Lane MD, Bolanowski MA, Kelly TJ Jr. Expression of specific mRNAs during adipose differentiation: identification of an mRNA encoding a homologue of myelin P2 protein. Proc. Natl. Acad. Sci. U.S.A. 1984; 81(17):5468-5472. [PubMed: 6206497]

Birsoy K, Chen Z, Friedman J. Transcriptional regulation of adipogenesis by KLF4. Cell Metab. 2008; 7(4):339-347. [PubMed: 18396140]

Burns KA, Vanden Heuvel JP. Modulation of PPAR activity via phosphory-lation. Biochim. Biophys. Acta. 2007

Cao Z, Umek RM, McKnight SL. Regulated expression of three C/EBP isoforms during adipose conversion of 3T3-L1 cells. Genes Dev. 1991; 5(9):1538-1552. [PubMed: 1840554]

Chawla A, Schwarz EJ, Dimaculangan DD, Lazar MA. Peroxisome proliferator-activated receptor (PPAR) gamma: adipose-predominant expression and induction early in adipocyte differentiation. Endocrinology. 1994; 135(2):798-800. [PubMed: 8033830]

Chen Z, Torrens JI, Anand A, Spiegelman BM, Friedman JM. Krox20 stimulates adipogenesis via C/ EBPbeta-dependent and -independent mechanisms. Cell Metab. 2005; 1(2):93-106. [PubMed: 16054051]

Christodoulides C, Lagathu C, Sethi JK, Vidal-Puig A. Adipogenesis and WNT signalling. Trends Endocrinol. Metab. 2009; 20(1):16-24. [PubMed: 19008118]

Darnell JE Jr. STATs and gene regulation. Science. 1997; 277(5332):1630-1635. [PubMed: 9287210]

Distel RJ, Ro HS, Rosen BS, Groves DL, Spiegelman BM. Nucleoprotein complexes that regulate gene expression in adipocyte differentiation: direct participation of c-fos. Cell. 1987; 49(6):835844. [PubMed: 3555845]

Doney AS, Fischer B, Leese G, Morris AD, Palmer CN. Cardiovascular risk in type 2 diabetes is associated with variation at the PPARG locus: a Go-DARTS study. Arterioscler. Thromb. Vasc. Biol. 2004; 24(12):2403-2407. [PubMed: 15486307]

Eberle D, Hegarty B, Bossard P, Ferre P, Foufelle F. SREBP transcription factors: master regulators of lipid homeostasis. Biochimie. 2004; 86(11):839-848. [PubMed: 15589694]

el Jack AK, Hamm JK, Pilch PF, Farmer SR. Reconstitution of insulin-sensitive glucose transport in fibroblasts requires expression of both PPARgamma and C/EBPalpha. J. Biol. Chem. 1999; 274(12):7946-7951. [PubMed: 10075691]

Fain JN, Ihle JH, Bahouth SW. Stimulation of lipolysis but not of leptin release by growth hormone is abolished in adipose tissue from Stat5a and b knockout mice. Biochem. Biophys. Res. Commun. 1999; 263(1):201-205. [PubMed: 10486277]

Farmer SR. Transcriptional control of adipocyte formation. Cell Metab. 2006; 4(4):263-273. [PubMed: 17011499]

Floyd ZE, Stephens JM. Interferon-gamma-mediated activation and ubiquitin-proteasome-dependent degradation of PPARgamma in adipocytes. J. Biol. Chem. 2002; 277(6):4062-4068. [PubMed: 11733495]

Floyd ZE, Stephens JM. STAT5A promotes adipogenesis in nonprecursor cells and associates with the glucocorticoid receptor during adipocyte differentiation. Diabetes. 2003; 52(2):308-314. [PubMed: 12540601]

Floyd ZE, Stephens JM. Control of peroxisome proliferator-activated receptor gamma2 stability and activity by SUMOylation. Obes. Res. 2004; 12(6):921-928. [PubMed: 15229330]

Gray S, Feinberg MW, Hull S, Kuo CT, Watanabe M, Sen-Banerjee S, DePina A, Haspel R, Jain MK. The Kruppel-like factor KLF15 regulates the insulinsensitive glucose transporter GLUT4. J. Biol. Chem. 2002; 277(37):34322-34328. [PubMed: 12097321]

Green H, Kehinde O. An established preadipose cell line and its differentiation in culture. II. Factors affecting the adipose conversion. Cell. 1975; 5(1):19-27. [PubMed: 165899]

Green H, Kehinde O. Spontaneous heritable changes leading to increased adipose conversion in 3T3 cells. Cell. 1976; 7(1):105-113. [PubMed: 949738] 
Hamm JK, Park BH, Farmer SR. A role for C/EBPbeta in regulating peroxisome proliferator-activated receptor gamma activity during adipogenesis in 3T3-L1 preadipocytes. J. Biol. Chem. 2001; 276(21):18464-18471. [PubMed: 11279134]

Harp JB, Franklin D, Vanderpuije AA, Gimble JM. Differential expression of signal transducers and activators of transcription during human adipogenesis. Biochem. Biophys. Res. Commun. 2001; 281(4):907-912. [PubMed: 11237746]

Hauser S, Adelmant G, Sarraf P, Wright HM, Mueller E, Spiegelman BM. Degradation of the peroxisome proliferator-activated receptor gamma is linked to ligand-dependent activation. J. Biol. Chem. 2000; 275(24):18527-18533. [PubMed: 10748014]

He W, Barak Y, Hevener A, Olson P, Liao D, Le J, Nelson M, Ong E, Olefsky JM, Evans RM. Adipose-specific peroxisome proliferator-activated receptor gamma knockout causes insulin resistance in fat and liver but not in muscle. Proc. Natl. Acad. Sci. U.S.A. 2003; 100(26):1571215717. [PubMed: 14660788]

Karin M, Liu Z, Zandi E. AP-1 function and regulation. Curr. Opin. Cell Biol. 1997; 9(2):240-246. [PubMed: 9069263]

Kawai M, Namba N, Mushiake S, Etani Y, Nishimura R, Makishima M, Ozono K. Growth hormone stimulates adipogenesis of 3T3-L1 cells through activation of the Stat5A/5B-PPARgamma pathway. J. Mol. Endocrinol. 2007; 38(1-2):19-34. [PubMed: 17242167]

Kim JB, Spiegelman BM. ADD1/SREBP1 promotes adipocyte differentiation and gene expression linked to fatty acid metabolism. Genes Dev. 1996; 10(9):1096-1107. [PubMed: 8654925]

Kim JB, Wright HM, Wright M, Spiegelman BM. ADD1/SREBP1 activates PPARgamma through the production of endogenous ligand. Proc. Natl. Acad. Sci. U.S.A. 1998; 95(8):4333-4337. [PubMed: 9539737]

Leff T, Mathews ST, Camp HS. Review: peroxisome proliferator-activated receptor-gamma and its role in the development and treatment of diabetes. Exp. Diabesity Res. 2004; 5(2):99-109. [PubMed: 15203881]

Lefterova MI, Lazar MA. New developments in adipogenesis. Trends Endocrinol. Metab. 2009; 20(3): 107-114. [PubMed: 19269847]

Lehmann JM, Moore LB, Smith-Oliver TA, Wilkison WO, Willson TM, Kliewer SA. An antidiabetic thiazolidinedione is a high affinity ligand for peroxisome proliferator-activated receptor gamma (PPAR gamma). J. Biol. Chem. 1995; 270(22):12953-12956. [PubMed: 7768881]

Li D, Yea S, Li S, Chen Z, Narla G, Banck M, Laborda J, Tan S, Friedman JM, Friedman SL, Walsh MJ. Kruppel-like factor-6 promotes preadipocyte differentiation through histone deacetylase 3dependent repression of DLK1. J. Biol. Chem. 2005; 280(29):26941-26952. [PubMed: 15917248]

Liao W, Nguyen MT, Yoshizaki T, Favelyukis S, Patsouris D, Imamura T, Verma IM, Olefsky JM. Suppression of PPAR \{gamma\} attenuates insulinstimulated glucose uptake by affecting both GLUT1 and GLUT4 in 3T3-L1 adipocytes. Am. J. Physiol. Endocrinol. Metab. 2007

Lin FT, Lane MD. CCAAT/enhancer binding protein alpha is sufficient to initiate the 3T3-L1 adipocyte differentiation program. Proc. Natl. Acad. Sci. U.S.A. 1994; 91(19):8757-8761. [PubMed: 8090719]

McKnight SL, Lane MD, Gluecksohn-Waelsch S. Is CCAAT/enhancer-binding protein a central regulator of energy metabolism? Genes Dev. 1989; 3(12B):2021-2024. [PubMed: 2697636]

Miles PD, Barak Y, He W, Evans RM, Olefsky JM. Improved insulin-sensitivity in mice heterozygous for PPAR-gamma deficiency. J. Clin. Invest. 2000; 105(3):287-292. [PubMed: 10675354]

Moitra J, Mason MM, Olive M, Krylov D, Gavrilova O, Marcus-Samuels B, Feigenbaum L, Lee E, Aoyama T, Eckhaus M, Reitman ML, Vinson C. Life without white fat: a transgenic mouse. Genes Dev. 1998; 12(20):3168-3181. [PubMed: 9784492]

Monajemi H, Zhang L, Li G, Jeninga EH, Cao H, Maas M, Brouwer CB, Kalkhoven E, Stroes E, Hegele RA, Leff T. Familial partial lipodystrophy phenotype resulting from a single-base mutation in deoxyribonucleic acid-binding domain of peroxisome proliferator-activated receptor-gamma. J. Clin. Endocrinol. Metab. 2007; 92(5):1606-1612. [PubMed: 17299075]

Mori T, Sakaue H, Iguchi H, Gomi H, Okada Y, Takashima Y, Nakamura K, Nakamura T, Yamauchi T, Kubota N, Kadowaki T, Matsuki Y, Ogawa W, Hiramatsu R, Kasuga M. Role of Kruppel-like 
factor 15 (KLF15) in transcriptional regulation of adipogenesis. J. Biol. Chem. 2005; 280(13): 12867-12875. [PubMed: 15664998]

Nanbu-Wakao R, Morikawa Y, Matsumura I, Masuho Y, Muramatsu MA, Senba E, Wakao H. Stimulation of 3T3-L1 adipogenesis by signal transducer and activator of transcription 5. Mol. Endocrinol. 2002; 16(7):1565-1576. [PubMed: 12089351]

Ohshima T, Koga H, Shimotohno K. Transcriptional activity of peroxisome proliferator-activated receptor gamma is modulated by SUMO-1 modification. J. Biol. Chem. 2004; 279(28):2955129557. [PubMed: 15123625]

Oishi Y, Manabe I, Tobe K, Tsushima K, Shindo T, Fujiu K, Nishimura G, Maemura K, Yamauchi T, Kubota N, Suzuki R, Kitamura T, Akira S, Kadowaki T, Nagai R. Kruppel-like transcription factor KLF5 is a key regulator of adipocyte differentiation. Cell Metab. 2005; 1(1):27-39. [PubMed: 16054042]

Pascual G, Fong AL, Ogawa S, Gamliel A, Li AC, Perissi V, Rose DW, Willson TM, Rosenfeld MG, Glass CK. A SUMOylation-dependent pathway mediates transrepression of inflammatory response genes by PPAR-gamma. Nature. 2005; 437(7059):759-763. [PubMed: 16127449]

Pellegrini S, Dusanter-Fourt I. The structure, regulation and function of the Janus kinases (JAKs) and the signal transducers and activators of transcription (STATs). Eur. J. Biochem. 1997; 248(3):615633. [PubMed: 9342212]

Picard F, Kurtev M, Chung N, Topark-Ngarm A, Senawong T, Machado DO, Leid M, McBurney MW, Guarente L. Sirt1 promotes fat mobilization in white adipocytes by repressing PPARgamma. Nature. 2004; 429(6993):771-776. [PubMed: 15175761]

Rosen ED, Sarraf P, Troy AE, Bradwin G, Moore K, Milstone DS, Spiegelman BM, Mortensen RM. PPAR gamma is required for the differentiation of adipose tissue in vivo and in vitro. Mol. Cell. 1999; 4(4):611-617. [PubMed: 10549292]

Schindler C, Darnell JE Jr. Transcriptional responses to polypeptide ligands: the JAK-STAT pathway. Annu. Rev. Biochem. 1995; 64:621-651. [PubMed: 7574495]

Schindler CW. Series introduction. JAK-STAT signaling in human disease. J. Clin. Invest. 2002; 109(9):1133-1137. [PubMed: 11994400]

Seale P, Kajimura S, Spiegelman BM. Transcriptional control of brown adipocyte development and physiological function—of mice and men. Genes Dev. 2009; 23(7):788-797. [PubMed: 19339685]

Semple RK, Chatterjee VK, O'Rahilly S. PPAR gamma and human metabolic disease. J. Clin. Invest. 2006; 116(3):581-589. [PubMed: 16511590]

Shang CA, Waters MJ. Constitutively active signal transducer and activator of transcription 5 can replace the requirement for growth hormone in adipogenesis of 3T3-F442A preadipocytes. Mol. Endocrinol. 2003; 17(12):2494-2508. [PubMed: 12970402]

Shimano H, Shimomura I, Hammer RE, Herz J, Goldstein JL, Brown MS, Horton JD. Elevated levels of SREBP-2 and cholesterol synthesis in livers of mice homozygous for a targeted disruption of the SREBP-1 gene. J. Clin. Invest. 1997; 100(8):2115-2124. [PubMed: 9329978]

Stephens JM, Butts M, Stone R, Pekala PH, Bernlohr DA. Regulation of transcription factor mRNA accumulation during 3T3-L1 preadipocyte differentiation by antagonists of adipogenesis. Mol. Cell Biochem. 1993; 123(1-2):63-71. [PubMed: 7694071]

Stephens JM, Butts MD, Pekala PH. Regulation of transcription factor mRNA accumulation during 3T3-L1 preadipocyte differentiation by tumour necrosis factor-alpha. J. Mol. Endocrinol. 1992; 9(1):61-72. [PubMed: 1515026]

Stephens JM, Morrison RF, Pilch PF. The expression and regulation of STATs during 3T3-L1 adipocyte differentiation. J. Biol. Chem. 1996; 271(18):10441-10444. [PubMed: 8631837]

Stewart WC, Morrison RF, Young SL, Stephens JM. Regulation of signal transducers and activators of transcription (STATs) by effectors of adipogenesis: coordinate regulation of STATs 1, 5A, and 5B with peroxisome proliferator-activated receptor-gamma and C/AAAT enhancer binding proteinalpha. Biochim. Biophys. Acta. 1999; 1452(2):188-196. [PubMed: 10559472]

Tanaka T, Yoshida N, Kishimoto T, Akira S. Defective adipocyte differentiation in mice lacking the C/EBPbeta and/or C/EBPdelta gene. EMBO J. 1997; 16(24):7432-7443. [PubMed: 9405372] 
Teglund S, McKay C, Schuetz E, van Deursen JM, Stravopodis D, Wang D, Brown M, Bodner S, Grosveld G, Ihle JN. Stat5a and Stat5b proteins have essential and nonessential, or redundant, roles in cytokine responses. Cell. 1998; 93(5):841-850. [PubMed: 9630227]

Tontonoz P, Hu E, Graves RA, Budavari AI, Spiegelman BM. mPPAR gamma 2: tissue-specific regulator of an adipocyte enhancer. Genes Dev. 1994; 8(10):1224-1234. [PubMed: 7926726]

Tontonoz P, Kim JB, Graves RA, Spiegelman BM. ADD1: a novel helix-loop-helix transcription factor associated with adipocyte determination and differentiation. Mol. Cell Biol. 1993; 13(8): 4753-4759. [PubMed: 8336713]

Wang ND, Finegold MJ, Bradley A, Ou CN, Abdelsayed SV, Wilde MD, Taylor LR, Wilson DR, Darlington GJ. Impaired energy homeostasis in C/EBP alpha knockout mice. Science. 1995; 269(5227):1108-1112. [PubMed: 7652557]

Wu Z, Bucher NL, Farmer SR. Induction of peroxisome proliferator-activated receptor gamma during the conversion of $3 \mathrm{~T} 3$ fibroblasts into adipocytes is mediated by C/EBPbeta, C/EBPdelta, and glucocorticoids. Mol. Cell Biol. 1996; 16(8):4128-4136. [PubMed: 8754811]

Wu Z, Rosen ED, Brun R, Hauser S, Adelmant G, Troy AE, McKeon C, Darlington GJ, Spiegelman BM. Cross-regulation of C/EBP alpha and PPAR gamma controls the transcriptional pathway of adipogenesis and insulin sensitivity. Mol. Cell. 1999; 3(2):151-158. [PubMed: 10078198]

Wu Z, Xie Y, Bucher NL, Farmer SR. Conditional ectopic expression of C/EBP beta in NIH-3T3 cells induces PPAR gamma and stimulates adipogenesis. Genes Dev. 1995; 9(19):2350-2363. [PubMed: 7557387]

Yahagi N, Shimano H, Hasty AH, Matsuzaka T, Ide T, Yoshikawa T, Amemiya-Kudo M, Tomita S, Okazaki H, Tamura Y, Iizuka Y, Ohashi K, Osuga J, Harada K, Gotoda T, Nagai R, Ishibashi S, Yamada N. Absence of sterol regulatory element-binding protein-1 (SREBP-1) ameliorates fatty livers but not obesity or insulin resistance in Lep(ob)/Lep(ob) mice. J. Biol. Chem. 2002; 277(22): 19353-19357. [PubMed: 11923308]

Yamashita D, Yamaguchi T, Shimizu M, Nakata N, Hirose F, Osumi T. The transactivating function of peroxisome proliferator-activated receptor gamma is negatively regulated by SUMO conjugation in the amino-terminal domain. Genes Cells. 2004; 9(11):1017-1029. [PubMed: 15507114]

Yarwood SJ, Sale EM, Sale GJ, Houslay MD, Kilgour E, Anderson NG. Growth hormone-dependent differentiation of 3T3-F442A preadipocytes requires Janus kinase/signal transducer and activator of transcription but not mitogen-activated protein kinase or p70 S6 kinase signaling. J. Biol. Chem. 1999; 274(13):8662-8668. [PubMed: 10085104]

Yeh WC, Cao Z, Classon M, McKnight SL. Cascade regulation of terminal adipocyte differentiation by three members of the C/EBP family of leucine zipper proteins. Genes Dev. 1995; 9(2):168181. [PubMed: 7531665]

Yokoyama C, Wang X, Briggs MR, Admon A, Wu J, Hua X, Goldstein JL, Brown MS. SREBP-1, a basic-helix-loop-helix-leucine zipper protein that controls transcription of the low density lipoprotein receptor gene. Cell. 1993; 75(1):187-197. [PubMed: 8402897] 


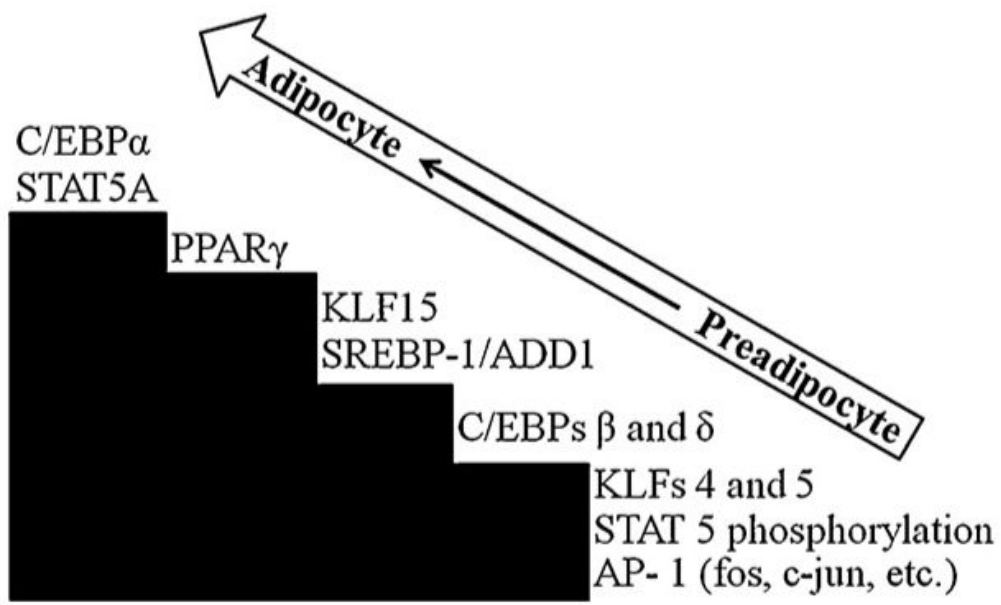

Fig. 1.

Transcription factor activation or expression during adipogenesis. 